\title{
Giant calvarial meningioma which obliterated superior sagittal sinus: Case report
}

\author{
Superior sagittal sinüsü invaze eden dev kalvaryal meningioma: Olgu sunumu
}

\author{
Murat Altaş*a, Mustafa Aras ${ }^{\mathrm{a}}$, Hanifi Bayaroğulları ${ }^{\mathrm{b}}$, Murat Karcıoğluc, Yurdal Serarslana, Nebi Yılmaz ${ }^{\mathrm{a}}$ \\ ${ }^{a}$ Department of Neurosurgery, Tayfur Ata Sökmen Medical Faculty, Mustafa Kemal University, Hatay, Turkey \\ ${ }^{b}$ Department of Radiology, Tayfur Ata Sökmen Medical Faculty, Mustafa Kemal University, Hatay, Turkey \\ ${ }^{c}$ Department of Anesthesiology and Reanimation, Tayfur Ata Sökmen Medical Faculty, Mustafa Kemal University, Hatay, Turkey
}

\begin{tabular}{|c|c|}
\hline ARTICL] & \\
\hline Article $\mathbf{H}$ & \\
\hline Received & 14 / 12 / 2011 \\
\hline Accepted & 27 / 12 / 2011 \\
\hline * Corresp & ice to: \\
\hline Murat Alt & \\
\hline Departme & Jeurosurgery, \\
\hline Tayfur At & nen Medical Faculty, \\
\hline Mustafa K & University, \\
\hline Hatay, Tu & \\
\hline e-mail: dr & urat@yahoo.com \\
\hline
\end{tabular}

Keywords:

Meningioma

Calvarium

Interosseous

Superior sagittal sinus

Management

Treatment

Anahtar Kelimeler:
Meningioma
Kalvaryum
İnterosseos
Superior sagittal sinus
Yönetim
Tedavi

Anahtar Kelimeler:

Meningioma

Kalvaryum

İnterosseos

Yönetim

Tedavi

\begin{abstract}
Interosseous meningioma, defined as meningiomas confined to the skull with no epidural or subcutaneous component, is a rarely encountered example of the primary meningiomas. It is usually a benign tumour and takes origin from arachnoids cap cells. Several etiological hypotheses have been asserted for interosseous meningiomas up to the present. The literature pointed out that the symptoms of the patients with meningiomas might vary. The findings of osteolysis and hyperostosis might also be seen by X-Ray radiograph imaging. Our case was a male and 21 years old. He admitted the polyclinics of neurosurgery with the complaint of convulsion. Intracranial component of the meningioma was measured as $90 \times 42 \mathrm{~mm}$ in MRI. Imaging indicated that this was a giant calvarium meningioma which diffusely skirted along to suture lines and obliterated superior sagittal sinus in a wide area. Clinical and radiological properties of the tumour were evaluated, and the responsible mechanisms from its pathogenesis are discussed in the light of the literature.

J. Exp. Clin. Med., 2012; 29:225-228
\end{abstract}

\section{ÖZET}

Kalvaryuma yerleşen interosse meningiomalar primer meningiomaların nadir bir örneğidir. Genellikle benign tümörlerdir ve araknoid kep hücrelerinden köken alırlar. Etyolojide çeşitli hipotezler öne sürülmüştür. Direk röntgen grafilerinde hiperosteosis ve osteolizis görülebilir. Meningiomalı hastaların semptomları değişkendir. Bizim olgumuz 21 yaşında erkek hasta, konvülziyon şikayetiyle başvuruyor. MRI da intrakranial komponenti de olan 90x42 mm olan diffuz olarak sütür hatları boyunca uzanan çok geniş bir alanda kafatası kemiklerini tutan ve superior sagittal sinüsü invaze eden dev bir kalvaryal meningioma olgusunun klinik, radyolojik özelliklerini değerlendirdik ve patogenezden sorumlu mekanizmaları literatür ışığında tartıștık.

J. Exp. Clin. Med., 2012; 29: 225-228

\section{Introduction}

Meningioma is usually a benign tumour and takes origin from arachnoids cap cells, which are non-neuroepitelial progenitor cells. It composes $13-26 \%$ of all intracranial tumours and is generally settled to parasagittal area and convexity (Bruner et al., 1998). Meningioma rarely invades subcutaneous tissue, paranasal sinus, orbit and calvarium without existing dural connection. Meningioma, emerging with hyperostosis, was reported as $4.5 \%$ in the studies conducted before (Bruner et al., 1998). End plate meningioma, generally with hyperostosis, occurs in the sphenoid wings or convexity. This association can be considered as a syndrome. In this article, a case of meningioma with calvarial hyperostosis and its clinical and radiological features were evaluated. Mechanisms which are responsible for its pathogenesis were discussed in the light of literature.

\section{Case}

The patient was male and 21-years-old. In the examination, there was a history of convulsion that has begun for 1.5 years before applying to our clinic. This had repeated several times, and anti-epileptic treatment had been started to the patient in where he had first applied. However, the patient applied our clinic after 4 months with complaints of convulsion during 
sleep and hearing loss on his left ear. There was not any other feature at his personal and family history.

\section{Neurological evaluation}

General condition of the patient was good, and his conscious was clear. The pupils were isochoric, and light reflexes were bilaterally positive. The cerebellar tests were normal. There was a sensory-neural hearing loss on the left ear. In the physical examination, there was a swelling at the frontoparietal region, which was not adhering to the overlying skin. There were no other pathological findings during other neurological examination.

\section{Radiological evaluation}

\section{$\mathrm{X}$-Ray radiography}

Marked thickening of the skull was noted throughout the calvarium. The thickening is most prominent near the coronal, sagittal, and lambdoid sutures. Radiographs of the skull revealed a well-defined area of osteolysis in both left and right frontoparietal region. Radiographic examination of the skull revealed hornlike hypercalcifications in both parietal regions and marked thickening of the calvarium (Fig. 1).

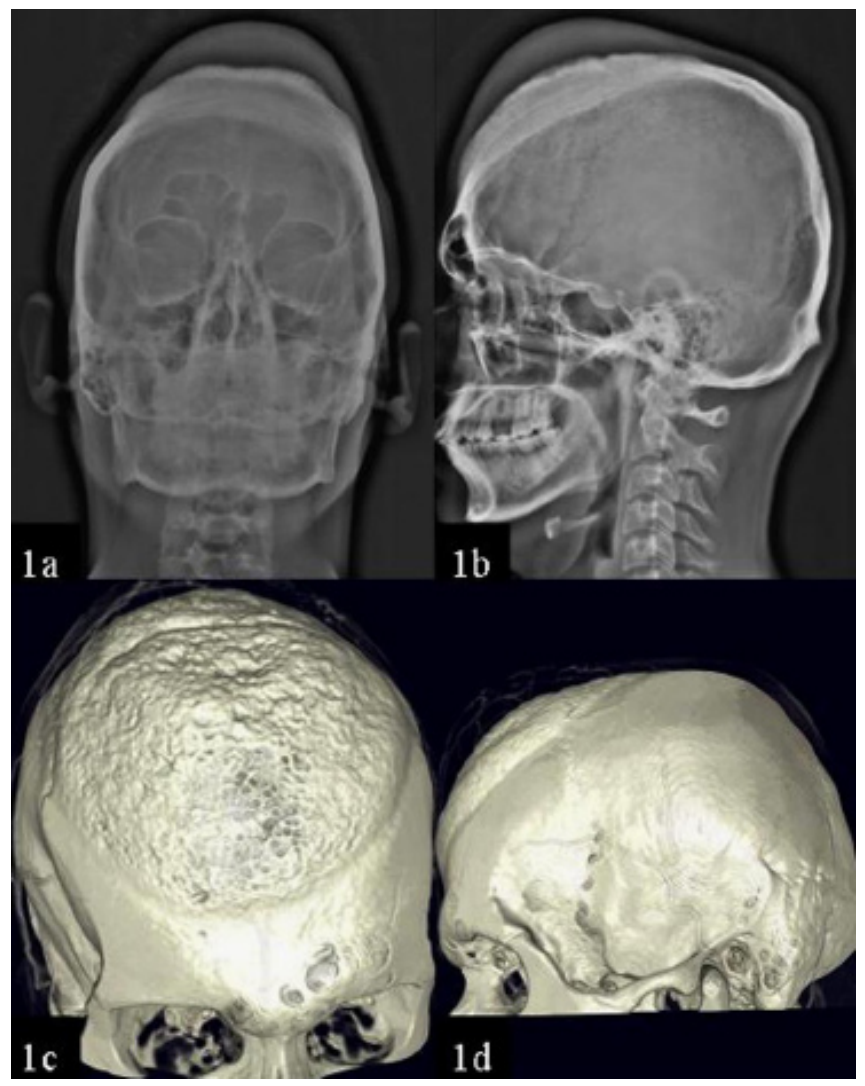

Fig. 1. (a-d): Antero-posterior and lateral cranial X-Ray, and 3D reconstructed CT of the skull. Radio graphs of the skull revealed a well-defined area of osteolysis in both left and right frontoparietal region.

\section{Contrast-enhanced brain CT}

Meningioma was seen at the right parietal lobe in supratentorial cross-sectional image and at supraventricular level in anterior cross-sectional image. It settled to Dura as broadbased, and was partially extending to the left of midline. It was a mass lesion at the size of $90 \times 42 \mathrm{~mm}$ approximately, and it was containing hypodense cystic areas. There was bla- zing hyperostosis area at the front parietal bones.

\section{Magnetic resonance imaging (MRI)}

MRI scan revealed diffuse thickening of the cranium, especially in superior sagittal sinus. MR imaging showed a solitary calvarial mass lesion of the frontoparietal region that was hypointense on T1-weighted and hyperintense on T2weighted images. This mass was also preceded to border of falx cerebri (Fig. 2).

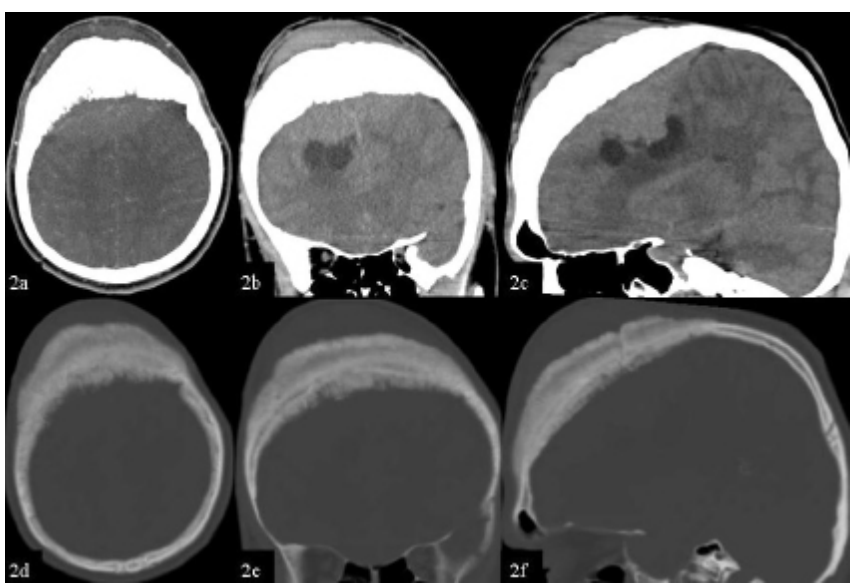

Fig. 2. (a-c): CT cross sections of parenchyma at axial, coronal and sagittal plane. (d-f): CT cross sections of the bone structure at axial, coronal, and sagittal plane. Imaging of the atypical meningioma, which holds the bone structure and has significant compression neigh boring brain parenchyma, and has cystic components and both intracranial and extracranial extensions.

The T1-weighted imaging following gadolinium injection demonstrated the prominent and homogeneous enhancement of the lesion (Fig. 3). MR imaging clearly revealed its intracranial parts. MR venography imaging brain meningioma. Parietal-convexity meningioma. Selective injection of the left middle meningeal artery shows inhomogeneous enhancing tumour. Intense vascularity is appreciated on the posterior aspect of the mass. Drainage veins are not seen (Fig. 3 e,f).

Cerebral angiogram obtained during the arterial phaseshowing the marked development of the external carotid system. The internal carotid system is small compared to the size of the head, which is defined by the superficial temporal artery and the occipital artery (arrows). Note the middle meningeal artery, which indicates the confines of the cranial cavity

\section{Surgical approach}

After the patient's head was properly fixed to the desired position in the supine position under general anaesthesia; skin and subcutaneous tissues were passed by bicoronal scalp incision. The mass that infiltrated both frontal and parietal bones and extended them were excised in a form of small fragments with the help of surgical engine. The bone structure of tumour was extremely fragile. The sagittal sinus was then merged with micro-surgical technique from both backside and front side of tumour tissue, and tumour tissue was excised (grade 1 resection of Simpson). The tumour tissue sample was excised from skin, bone and dural mater for the pathological evaluation. A bone defect, approximately $14 \times 10 \mathrm{~cm}$, was observed in the patient's cranium. 


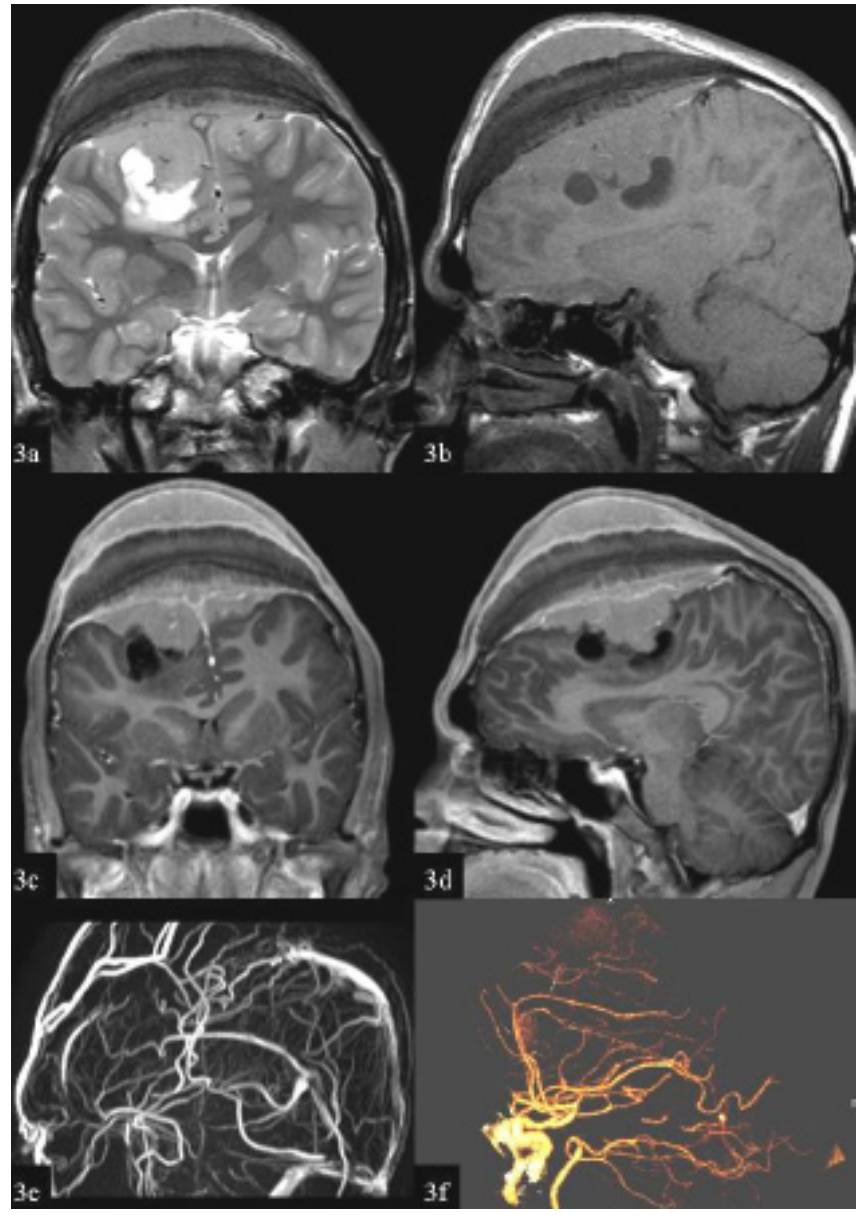

Fig. 3. (a,b): Coronal T2-weighted MR image and sagittal T1weighted MRI. (c,d): Coronal and sagittal T1-weighted contrast-enhanced cross sections; atypical meningioma stained with contrast and in the fronto-parietal region, intracranial and subgaleal extracranial extension; adjacent to bone structure, its cystic component, its compress to the surrounding brain parenchyma and corpus callosum, (e): MR venography; mass lesion that obliterated the proximal segment of superior sagittal sinus; increased number of meningeal and intraparenchymal venous structures which is secondary to drainage vein of mass and obliteration of sagittal sinus. (f): Cranial CT angiography; arterial structures feeding meningioma at the vertical level arising from the MCA and meningeal arteries.

\section{Postoperative assessment}

The patient's conscious was closed. Therefore, the patient was hospitalized to intensive care unit. Glasgow Coma Scale (GCS) was seven. Following the anti-edema treatment, GCS was increased to 10 point at the 8 th postop days. Following days, GCS was 16 point and improved at the postop 14th days. During neurological examination, the patient was observed $+3 / 5$ tetra-paretic. The patient's left lower extremity had $3 / 5$ power at the postop 12 th months. There was no loss of strength in other extremities. The patient was underwent a cranioplasty surgery in the postop 12th months (Fig. 4).

\section{Discussion}

The incidence of leading to hyperostosis in meningiomas is variable according to the literature. Although Cushing and Eisenhardt reported the incidence as $25 \%$, this rate was reported to be $49 \%$ by different authorities.

Echlin firstly stated the relationship between hyperostosis

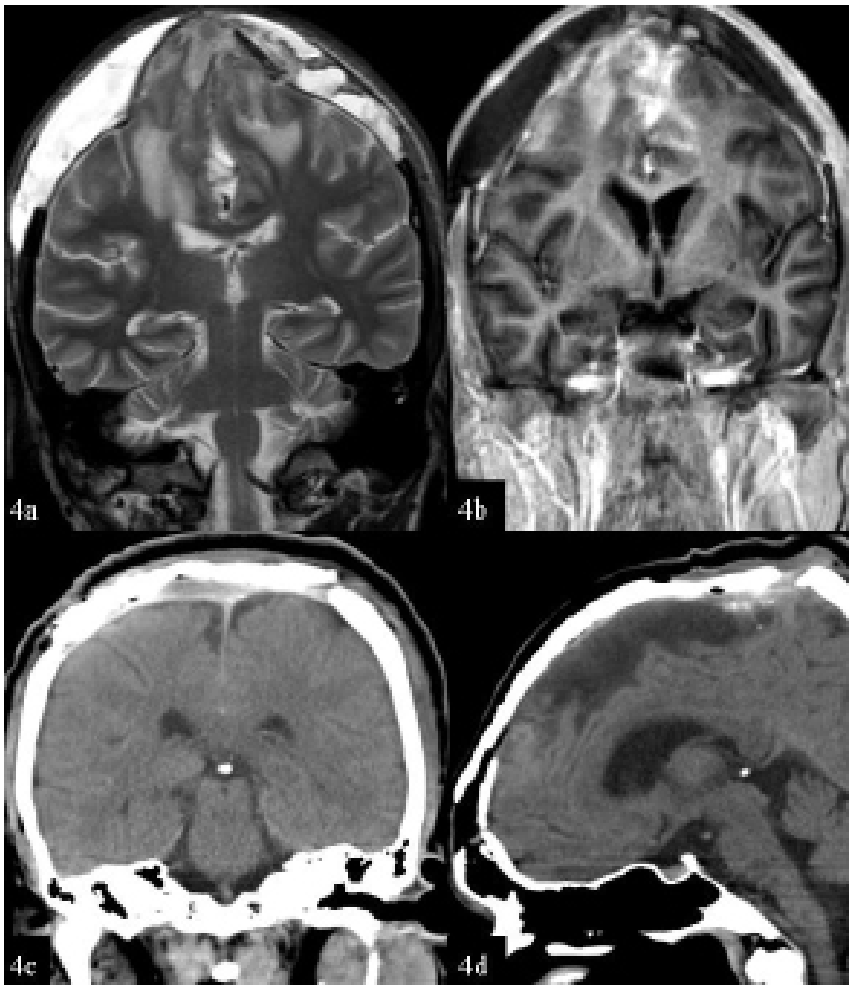

Fig. 4. Image that was performed in early period, (a): Coronal T2weighted MR image, (b): Coronal T1-weighted MRI; image following completely removed mass lesion; contusion and edema areas in the brain parenchyma around operation field; large defects secondary to craniectomia in the bone structure. (b), (c,d): The coronal and sagittal CT cross sections in late period; areas where the mass localized; changes similar to encephalomalacia; tissue graft secondary to the closure of large bone defects.

and bone invasion (Echlin, 1934). Hoye et al. (1960) separated meningiomas to 4 subgroups according to the cranial localization (Hoye et al., 1960; Al-Khawaja et al., 2007). Primary intracranial tumours skirt along out of cranium (AzarKia et al., 1974). Tumour cell arises from the arachnoids cell and settles through nerve sheath (Bigner et al., 1998). Tumour cell emerges outside of cranium without any connection to cranial nerve or foramens (Crawford et al., 1995). Benign-looking meningiomas with extra cranial metastases. In our case, the meningiomas were observed in the calvarias and overlying through scalp. There was no connectivity with foramina, and its pathogenesis was controversial.

The hypothesis of Azar-Kia et al. (1974) was that the dura mater is trapped in the suture lines in the embryonic development period and raised to interosseous meningiomas. Meningiomas are commonly associated with cranial sutures, but multiple sutures were stated in a few cases. However, in our case, tumour behaves extending along the coronal suture line by following the sagittal suture.

Crawford et al. (1995) reported that there was no direct relationship between interosseous meningiomas and trauma. In a different approach of Shuangshoti et al. (1971) reported that because multipotential mesenchyme cells are able to differentiate into different tissues, Meningiomas may arise from these mesenchyme precursors. That is bale to emerge as a result of stimulus. In our case, the tumour had widely and symmetrically invaded the cranium and the scalp. We suggested that changes in osteoblastic bone are responsible for this 
invasion.

According to the literature, the distribution ratios of emerging localization regarding tumour tissue were $32 \%$ for parietal region, $25 \%$ for frontal area, $10 \%$ for temporal area, $6 \%$ for occipital region, $16 \%$ for frontoparietal region, $4.5 \%$ for frontotemporal region, $3 \%$ for temporoparietal region and $3 \%$ for diffuse. The present case was classified as diffuse. In the literature, sclerosis of bone was observed in $51 \%$ of cases, lytic bone in $33 \%$ and the mixed type in $15 \%$ (Al-Khawaja et al., 2007).

In the pathologic evaluation, distributions of sub-types were reported as $62 \%$ for meningothelial, $18 \%$ for transitional, $6 \%$ for fibroblastic, $6 \%$ for psammomatous and $8 \%$ for malignant meningiomas (Shuangshoti et al., 1971). The pathology of our case was meningothelial.

Hyperostosis, osteolysis or mixt structure (hyperostosis +osteolysis) may be seen in interosseous meningioma by radiography Crawford et al. in a study, including 34 patients with interosseous meningioma Echlin, (1934), reported the ingredients which included hyperostosis in 20 patients (59\%), osteolytic changes in 11 patients (32\%) and mixt structure of osteolysis and hyperostosis in only two patients $(6 \%)$.

End plaque meningioma, osteoma, osteosarcoma, Paget's disease and fibrous dysplasia must be considered among osteoblastic subtype for the differential diagnosis of intraosseous meningiomas. Hemangioma, chondromas, chondrosarcoma, dermoid, epidermoid tumour, brown tumour, multiple myeloma, plasmacytoma, giant cell tumour, aneurismal bone cyst, eosinophilic granuloma and metastatic cancers must be considered among osteolytic sub-types.

Interosseous calvarium meningiomas are benign and slow-growing tumours according to proportion of its histological grade. It may show more malignant changes than intracranial meningiomas. Surgical resection is the first choice of treatment. However, the complications of surgical resection should be known well. Because its morbidity rate is high in the tumours which sinus was obliterated and settled upon sensitive region.

\section{REFERENCES}

Al-Khawaja, D., Murali, R., Sindler, P., 2007. Primary calvarial meningioma. J. Clin.Neurosci. 14, 1235-1239.

Azar-Kia, B., Sarwar, M., Marc, JA., 1974. Intraosseous meningioma. Neuroradiology. 6, 246-253.

Bruner, J.M., Tien, R.D., Enterline, D.S., 1998. Tumors of the meninges and related tissues. In: Russell and Rubinstein's Pathology of Tumors of the Nervous System 6th Edition (Edited by: Bigner DD, McLendon RE, Bruner JM). London, UK: Arnold. 67-139.

Crawford, T.S., Kleinschmidt-DeMasters, B.K., Lillehei, K.O., 1995. Primary intraosseous meningioma. Case report. J. Neurosurg. 83, $912-$ 915.

Echlin, F., 1934. Cranial osteomas and hyperostosis produced by meningeal fibroblastomas. Arch. Surg. 28, 357-405.

Hoye, S.J., Hoar, C.S. Jr., Murray, J.E., 1960. Extracranial meningioma presenting as a tumor of the neck. Am. J. Surg. 100, 486-489.

Shuangshoti, S., Netsky, M.G., Fitz-Hugh, G.S., 1971. Parapharyngeal meningioma with special reference to cell of origin. Ann. Otol. Rhinol. Laryngol. 80, 464-473. 